Revista do Departamento de Geografia
Universidade de São Paulo
WwW.revistas.usp.br/rdg
ISSN 2236-2878
V.34 (2017)

\title{
Caracterização Geoambiental e Compartimentação Geomorfológica da Serra do Quincuncá e Entorno, Nordeste do Brasil
}

\section{Geo-Environmental Characterization and Geomorphological Compartmentalization of Quincuncá Mountain Range and its Surroundings, Northeast of Brazil}

Resumo: O conhecimento do quadro natural da Serra do Quincuncá, localizada no semiárido brasileiro, foi desenvolvido com a preocupação de contribuir no entendimento da sua compartimentação geomorfológica. No entanto, o caráter integrativo da pesquisa geomorfológica fornece importantes subsídios ao conhecimento da realidade espacial, contribuindo no planejamento ambiental no sentido de encontrar alternativas para melhorar a qualidade de vida das populações locais. O mapeamento das unidades geomorfológicas foi realizado com base em fotointerpretações da textura e rugosidade de conjuntos de formas de relevo que estão associados às principais estruturas geológicas regionais a partir de diversos sensores remotos, imagens do satélite SPOT5 e Modelo Digital de Elevação (MDE). A caracterização do quadro natural foi elaborada a partir de trabalhos de campo entre 2014 e 2016, e interpretação de cartas temáticas em escalas diversas. Foram identificadas duas unidades morfoestruturais (superfícies elevadas e rebaixadas), sendo individualizadas em superfícies morfoesculturais distintas (superfícies de erosão dissecadas em cristas e colinas, superfície aplainada, superfícies tabulares sustentadas por lateritas e superfícies de deposição recente), todas estas esculpidas sob diferentes agentes modeladores exógenos.

Palavras-chave: Geomorfologia Estrutural; Semiárido; Maciço Residual.

\author{
Abner Monteiro Nunes Cordeiro \\ Universidade Estadual do Ceará \\ abnermncordeiro@gmail.com \\ Frederico de Holanda Bastos \\ Universidade Estadual do Ceará \\ fred.holanda@uece.br \\ Rubson Pinheiro Maia \\ Universidade Federal do Ceará \\ rubsonpinheiro@yahoo.com.br
}

Abstract: The natural framework knowledge of the Quincuncá mountain range, located in the Brazilian semi arid, was developed with the aim of contributing to the understanding of its geomorphological compartmentalization. However, the integrative nature of the geomorphological research provides important subsidies to the knowledge of the spatial reality, contributing in the environmental planning in the sense of finding alternatives to improve the quality of the local population's life. The mapping of the geomorphological units was performed based on photo interpretations of the texture and roughness of sets of relief shapes which are associated to the main regional geological structures from several remote sensors, SPOT5 satellite images and Digital Elevation Model (MDE). The natural framework characterization was elaborated from field works between 2014 and 2016, and interpretation of thematic charts at different scales. Two morphostructural units were identified (elevated and undercut surfaces) and individualized on distinct morphoscultural surfaces (dissected erosion surfaces in ridges, hills, planed, tabular surfaces supported by laterites and surfaces of recent deposition), all of these sculpted under different modeling exogenous agents.

Keywords: Structural Geomorphology; Semiarid; Residual Mass. 


\section{INTRODUÇÃO}

No Nordeste brasileiro, o relevo documenta importantes episódios de evolução morfotectônica. Organizado em torno de paleosuperfícies, a região apresenta diversos compartimentos geomorfológicos derivados de eventos tectônicos, como o Ciclo Brasiliano e a separação América do Sul/África (MAIA; BEZERRA, 2014). Ambos eventos geraram várias morfologias com controle estrutural, de onde podem-se destacar os maciços cristalinos alinhados segundo diferentes zonas de cisalhamento.

Todo o Domínio Rio Grande do Norte (DRGN), da porção setentrional da Província Borborema, foi afetado por intrusões graníticas de idade brasiliana ( 750 a $540 \mathrm{Ma}$ ) (BRITO NEVES Neves et al., 2001), geralmente, associadas a extensas zonas de cisalhamento transcorrentes de direção predominantemente NE-SW e E-W, reativadas de forma rúptil no início do Cretáceo, durante a ruptura do Gondwana, originando trends de falhamentos também de direção NE-SW e E-W (CASTRO et al., 2012).

O caráter granítico dos corpos intrusivos da Província Borborema geralmente forma relevos residuais, expostos pela denudação das antigas áreas orogênicas e posteriormente retrabalhados por agentes erosivos associados aos diversos sistemas morfogenéticos cambiantes ao longo do tempo (CORRÊA et al., 2010), que se elevam de modo disperso pelos sertões semiáridos do Nordeste brasileiro.

No Estado do Ceará, os últimos atos da Orogênese Brasiliana tiveram lugar em torno de 532 Ma (VAUCHEZ et al., 1995). Esses episódios estavam ainda em curso, quando processos de fissão vieram a fragmentar o supercontinente Panotia (PEULVAST; CLAUDINO SALES, 2007). No seio da Província Borborema, os processos de extensão crustal associados a esses últimos estágios e à fissão do Panotia foram responsáveis pela formação de bacias intracratônicas e ocorrência de uma atividade vulcânica e plutônica intensa (SCHOBBENHAUS et al., 1984), em razão do que se formaram rochas extrusivas e corpos graníticos diversos (NASCIMENTO; MEDEIROS; GALINDO, 2015).

No Nordeste brasileiro, por muito tempo, quando se falava em serras tratava-se sempre das serras úmidas, ambientes de exceção, expressão engenhosa introduzida há pouco tempo pelos geógrafos (AB'SÁBER, 1999). No entanto, se foi necessário destacá-las do conjunto geral dos maciços cristalinos do semiárido nordestino, certamente também existem serras secas, cuja omissão evidencia sua pouca importância em termos de ocupação humana e produtividade.

As serras secas tratam-se de maciços residuais, em rochas do embasamento cristalino, com níveis altimétricos médios oscilando entre $500-700 \mathrm{~m}$, podendo ultrapassar altitudes da ordem de $1.000 \mathrm{~m}$, como é o caso da Serra das Matas $(1.145 \mathrm{~m})$, localizada na região centro-oeste do Estado do Ceará. Esses relevos serranos, com dimensões e configurações variadas, dispersam-se por todo o território semiárido do Nordeste brasileiro, englobando, conjuntamente, uma área de $40.375,73 \mathrm{~km}^{2}$, equivalente a $4,73 \%$ do território semiárido (BRASIL, 2005). As serras secas se diferenciam dos enclaves úmidos, que, com frequência, constituem níveis mais elevados, com condições edafoclimáticas e hidrológicas mais favoráveis, e apresentam-se como verdadeiros ambientes de exceção no contexto dos sertões nordestinos.

A Serra do Quincuncá, localizada na mesorregião centro sul do Estado Ceará (Figura 1), disposta de forma alongada e fortemente dissecada por vales incisos, constitui um importante registro de evolução morfotectônica e morfoclimática regional. Trata-se de um relevo residual cristalino, disperso pela depressão sertaneja, ocupando uma área $775,09 \mathrm{~km}^{2}$ e, invariavelmente, alinhado na direção NE-SW, modelado em granitoides de idade sin a tardi-proterozoica, relativos à Orogênese Brasiliana. Sua evolução geomorfológica é comandada por processos de erosão diferencial, em virtude de sua constituição geológica resistente derivar de rochas intrusivas plutônicas ou parametamórficas no caso das cristas alongadas, nas direções dos trends estruturais, que compõem o seu entorno.

A Serra do Quincuncá, apesar de ser considerada um maciço residual seco, pelas abordagens regionalistas, concentra melhores condições ambientais nos planos geomorfológico, pluviométrico e pedológico, para fins de utilização agrícola, que a diferencia dos demais maciços serranos secos. 
Tendo em vista as potencialidades naturais, principalmente, pedológica, da Serra do Quincuncá, associada a uma crescente pressão exercida pela ação antrópica, além da ausência de áreas protegidas e da dificuldade de gerenciar corretamente os procedimentos de licenciamentos ambientais, que acabam sendo responsáveis pela liberação de construções e/ou desmatamentos impróprios em ambientes fortemente instáveis, o presente trabalho teve como finalidade a análise do quadro natural e compartimentação geomorfológica desse maciço e do entorno imediato, para fins de planejamento ambiental.

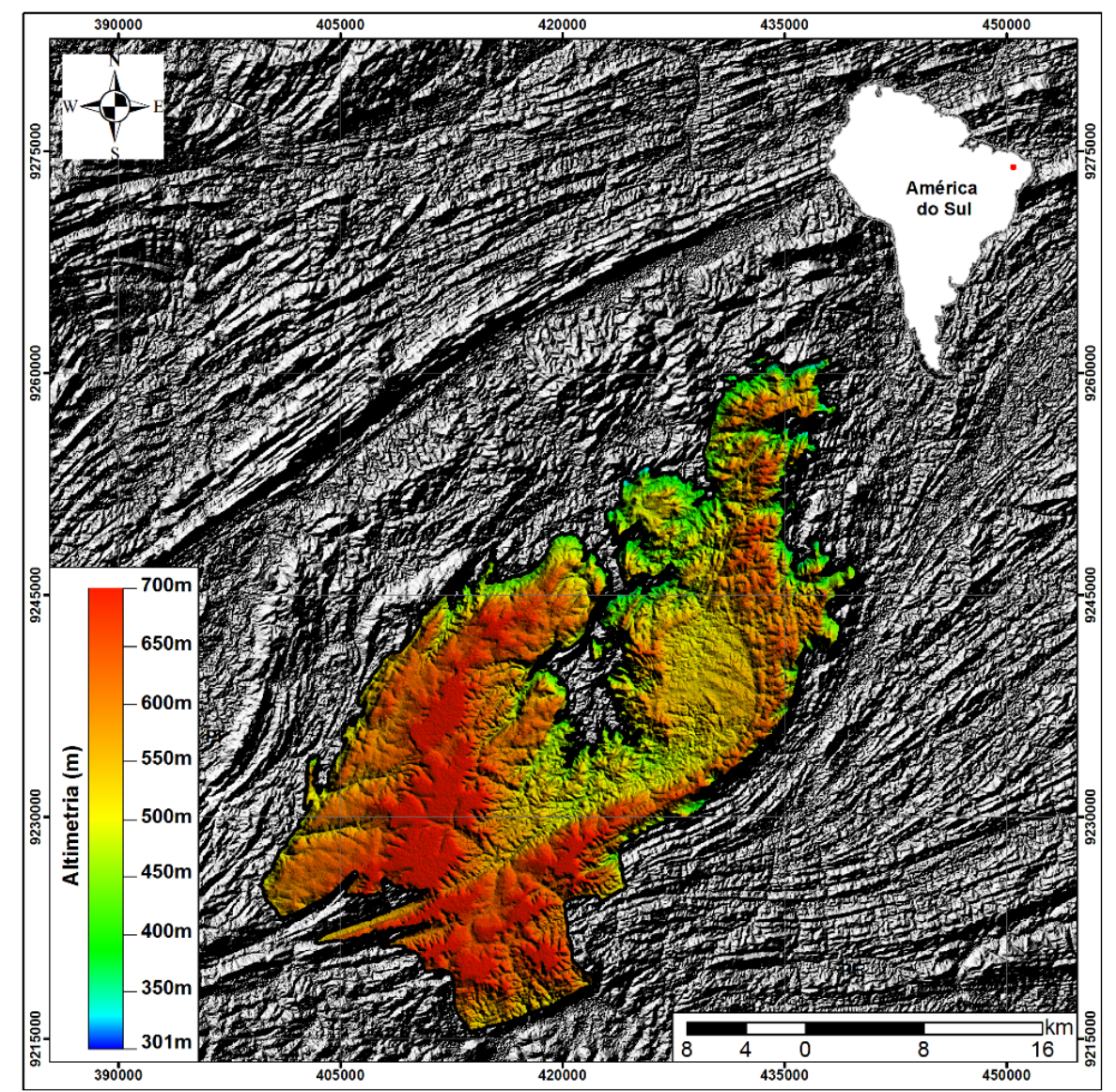

Figura 1: Delimitação da Serra do Quincuncá (MDT) e entorno. Fonte: elaborado pelo autor (2016). Projeção Universal Transversa de Mercator-UTM/Datum SIRGAS 2000, Zona 24S.

\section{MATERIAL E MÉTODOS}

Estudos ambientais integrados em um recorte espacial regional, como é o caso da Serra do Quincuncá e entorno, demandam um grande acervo de informações geoespaciais, tendo em vista a complexidade inerente a esse tipo de análise. Dessa forma, torna-se fundamental um extenso levantamento de dados em órgãos públicos, artigos científicos e anais.

Face ao exposto, a presente pesquisa teve acesso as bases cartográficas geológicas e pedológicas disponibilizadas, respectivamente, pela Companhia de Pesquisa de Recursos Minerais-CPRM (2003) e Fundação Cearense de Meteorologia e Recursos Hídricos-FUNCEME (2012). Além disso, foram realizadas reinterpretações das informações existentes nos mapas geomorfológicos produzidos por Peulvast e Claudino Sales (2003) e Peulvast e Bétard (2015).

$\mathrm{Na}$ área de estudo foram realizados dois levantamentos pedológicos: um geral, de reconhecimento da distribuição espacial das coberturas pedológicas em função de níveis topográficos, dos relevos e das litologias inter-relacionadas; e um ao nível de reconhecimento de média intensidade, em setores pré-selecionados nas etapas de campo. 
A representação tridimensional do relevo foi feita através dos produtos do projeto TOPODATA/INPE, com resolução de $30 \mathrm{~m}$. Além disso, também, foram utilizadas as imagens do satélite SPOT5, cedidas pelo Instituto de Pesquisa e Estratégia Econômica do Ceará-IPECE (2012).

A avaliação das condições climáticas e paleoclimáticas foram feitas tomando como base dados fornecidos por Ceará (2016), além de outros trabalhos como Morais Neto, Hegarty e Karner (2005) e Peulvast e Bétard (2015).

O limite do Maciço do Quincuncá foi estabelecido levando em consideração a cota altimétrica de $450 \mathrm{~m}$. Já a proposta de compartimentação geomorfológica foi feita adotando-se como critério fundamental a morfologia do relevo, tendo em vista que as unidades geomorfológicas, na escala de compartimentação adotada, apresentam uma certa uniformidade dos demais componentes naturais.

Para a confecção dos mapas, o software utilizado para o tratamento dos dados foi o Sistema de Informações Geográficas (SIG) Quantum GIS 2.14, que possibilitou todo o tratamento dos dados vetoriais e matriciais, permitindo a criação de um banco de dados georreferenciados, sendo todos os arquivos submetidos à projeção cartográfica Universal Transversa de Mercator (UTM), utilizando-se o Datum Sistema de Referência Geocêntrico para as Américas de 2000 (SIRGAS2000).

\section{RESULTADOS}

\subsection{Localização e Caracterização Do Quadro Natural}

A Serra do Quincuncá se insere no contexto geológico e tectônico da porção setentrional da Província da Borborema, DRGN, onde Peulvast e Claudino Sales (2007) apontaram a presença de um vasto anfiteatro de erosão voltado para o oceano Atlântico, que se estende dos limites da Bacia do Parnaíba, a oeste, ao Cráton do São Francisco, ao sul, comportando um complexo de formas estruturais soerguidas e amplamente trabalhadas por processos erosivos (Figura 2).

Na porção sul desse anfiteatro, denominado por Gurgel et al. (2013) de Anfiteatro Borborema ( $450 \mathrm{~km}$ de diâmetro), estabelece-se a área de estudo, estruturada em diversos litotipos cristalinos datados do Pré-Cambriano (BRASIL, 2003), cujos limites são marcados por uma série de desnivelamentos topográficos, cuja gênese epirogênica, possivelmente, está relacionada aos esforços distensivos responsáveis pela abertura do Atlântico Sul, que proporcionaram a série de rifts intracontinentais, de direção NE-SW, denominado Eixo de Rifteamento Cariri-Potiguar, e consequente processos de denudação.

A Serra do Quincuncá, situada acima da cota de 450m, é um dos numerosos maciços graníticos, com dimensões variadas que pontuam o semiárido cearense, correspondendo ao afloramento e resistência litológica do núcleo intrusivo, representado pelas Suítes Itaporanga (NP3y2i), Serra do Deserto (PP4sd) e Gabroide (NP3ס2), em detrimento dos gnaisses, micaxistos e ortognaisses (Figura 3), que constituem o embasamento metamórfico encaixante, composto, predominantemente, por alinhamentos de cristas residuais, inselbergs, colinas convexas e vales de drenagens, colmatados por colúvio-alúvio, com direções preferenciais NE-SW. Portanto, a origem do Maciço do Quincuncá está associada ao volumoso plutonismo Ediacariano, relacionado ao Ciclo Brasiliano/Panafricano, e às propriedades geoquímicas das rochas encaixantes que induzem ao aumento da intensidade do intemperismo químico, viabilizando a ação morfogenética por meio dos processos fluviais e movimentos de massa. Esses processos morfodinâmicos promovem o rebaixamento do relevo constituído por rochas pouco competentes e as mais resistentes permanecem como sobressaltos topográficos, evidenciando assim os núcleos granitoides na forma de maciços.

Esse maciço residual apresenta eixo principal de $52,25 \mathrm{~km}$, sugerindo uma evolução ligada à tendência NE-SW do sistema de zonas de cisalhamento transcorrentes dextrais, datadas do Neoproterozoico. O controle do alojamento e a forma alongada do maciço mostram boa concordância com sistema de zonas de cisalhamento transcorrente de cinemática dextral NE-SW, associadas ao Lineamento de Patos. 
Geomorfologicamente, o relevo da área de estudo, corresponde a um conjunto de terras altas contínuas, ao norte da Chapada do Araripe, desenvolvidos em litotipos variados, com destaque para o Maciço do Quincuncá, as cristas residuais e as depressões sertanejas, todos com padrões de dissecação orientados segundo as direções das principais zonas de cisalhamento. As altitudes variam de 240 a $310 \mathrm{~m}$ nas planícies fluviais aumentando suas amplitudes em direção aos platôs da Serra do Quincuncá, capeados por uma duricrosta laterítica, o que lhes confere topos tabulares, onde podem ultrapassar os $700 \mathrm{~m}$.

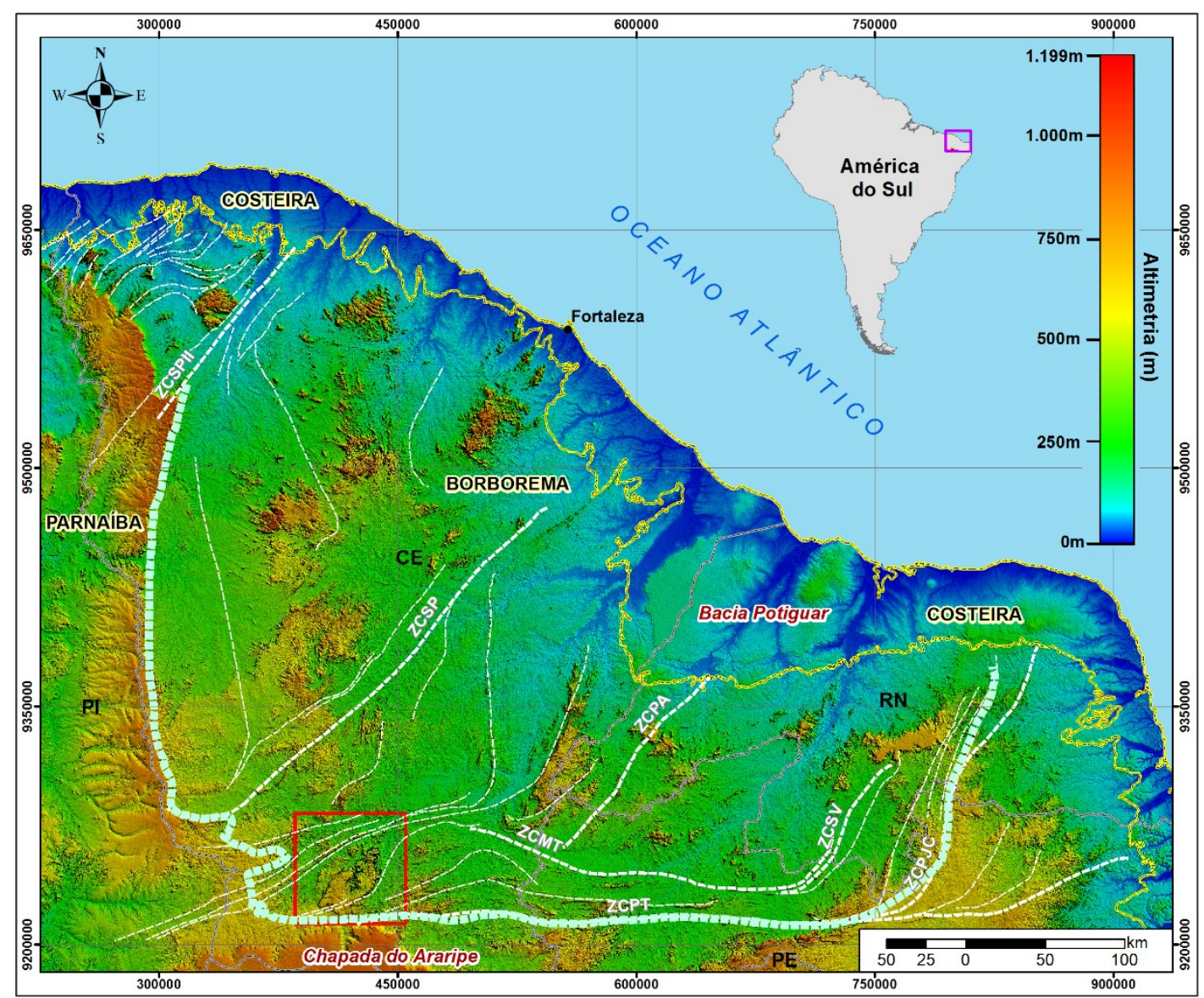

Figura 2: Localização da porção setentrional da Província Borborema com ênfase para o Anfiteatro Borborema e as zonas de cisalhamento. Fonte: elaborado pelo autor. Legenda: ZCSPII: Zona de Cisalhamento Sobral Pedro II; ZCSP: Senador Pompeu; ZCPA: Portalegre; ZCMT: Malta; ZCSV: São Vicente; ZCPJC: Picuí João Câmara; ZCPT: Patos. Traço vermelho: área de estudo; Pontilhado azul claro: delimitação do Anfiteatro Borborema; Pontilhado amarelo: Província Costeira; Pontilhado branco: Lineamentos estruturais.

$\mathrm{Na}$ área de estudo, a erosão diferencial que se estabeleceu distinguiu o embasamento metamórfico encaixante do núcleo granitoide intrusivo na forma de maciço. Dessa forma, a erosão de zonas de cisalhamento conduziu a progressiva exumação da Serra do Quincuncá. As escarpas oriental e ocidental do maciço encontram-se delimitadas pelas zonas de cisalhamento Farias Brito e Tatajuba, ao longo das quais a intrusão ocorreu.

Os granitos e granodioritos de granulação média a grossa que sustentam a Serra do Quincuncá, por serem mais jovens e ainda não terem passado por um intenso processo de metamorfismo oferecem maior resistência aos processos denudacionais, formando feições elevadas, onde estão localizadas superfícies tabuliformes, com coberturas lateríticas de espessura variável, oriundas de alterações supergênicas de rochas intrusivas, resultantes da ação intensa do intemperismo químico sobre o embasamento granítico, em condições ambientais pretéritas úmidas. Do ponto de vista geomorfológico, esses platôs ocorrem como superfícies tabulares similares a chapadas, com escarpas abruptas e contornos irregulares (Figura 4). 


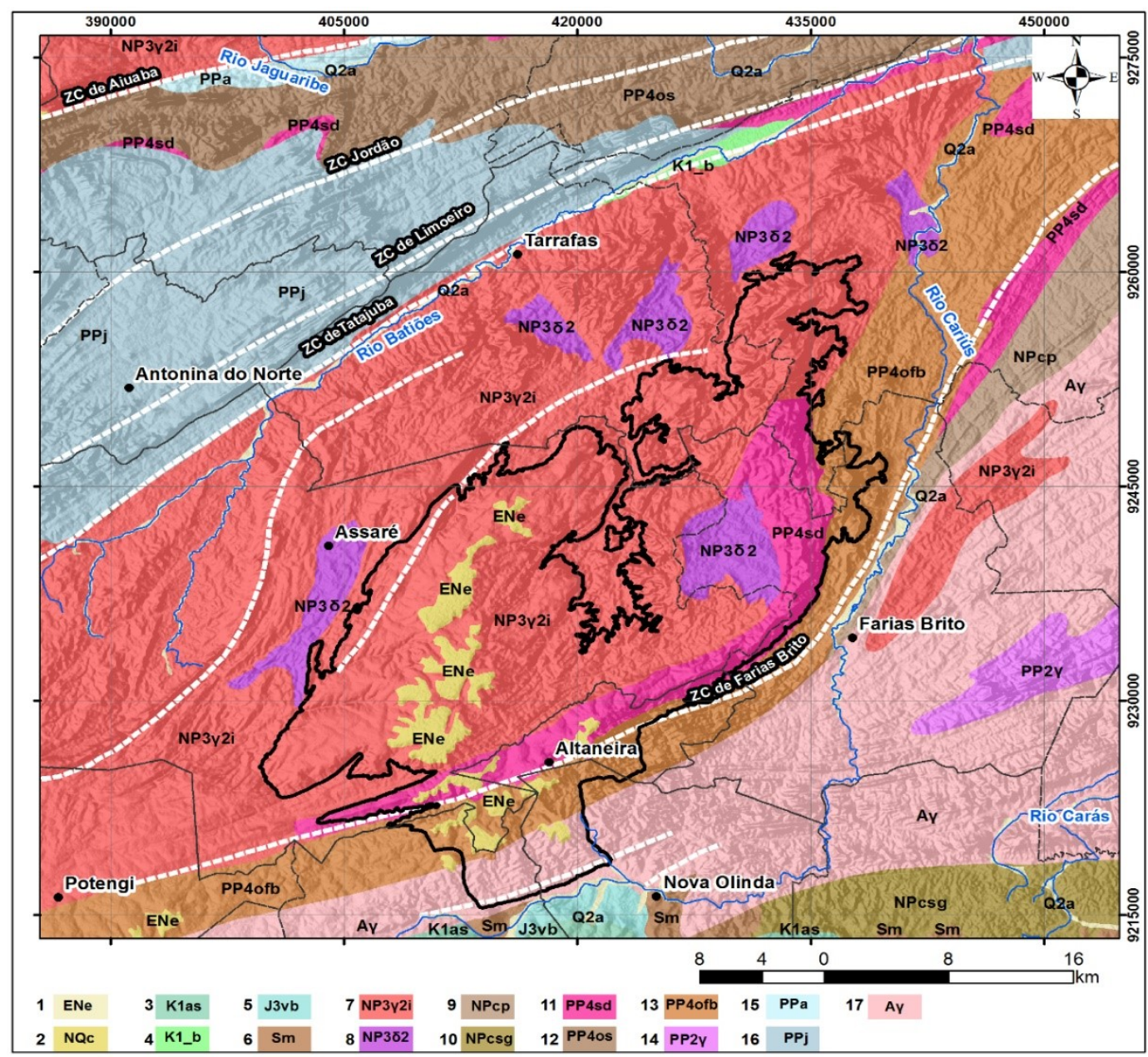

Figura 3: Litologia da Serra do Quincuncá e entorno. Legenda: 1. Cobertura eluvial; 2. Depósitos aluviais; 3. Formação Santana (folhelhos e calcários); 4. Formação Rio dos Bastiões (arenitos); 5. Formação Brejo Santo (folhelhos e siltitos); 6. Formação Mauriti (arenitos); 7. Suíte Itaporanga (granitos); 8. Suíte Gabroide (dioritos e gabros); 9. Formação Caipu (micaxistos); 10. Formação Santana dos Garrotes (micaxistos); 11. Suíte Serra do Deserto (augenortognaisses); 12. Formação Santarém (micaxistos e quartzitos); 13. Formação Farias Brito (gnaisses e metacalcários); 14. Ortognaisses granito-granodioríticos; 15. Paragnaisses e ortognaisses; 16. Complexo Jaguaretama (ortognaisses migmatizados); 17. Ortognaisses. Traço preto: Serra do Quincuncá; pontilhado branco: zonas de cisalhamento pré-cambrianas. (Elaborado a partir da edição de shape de geologia da BRASIL, 2003).

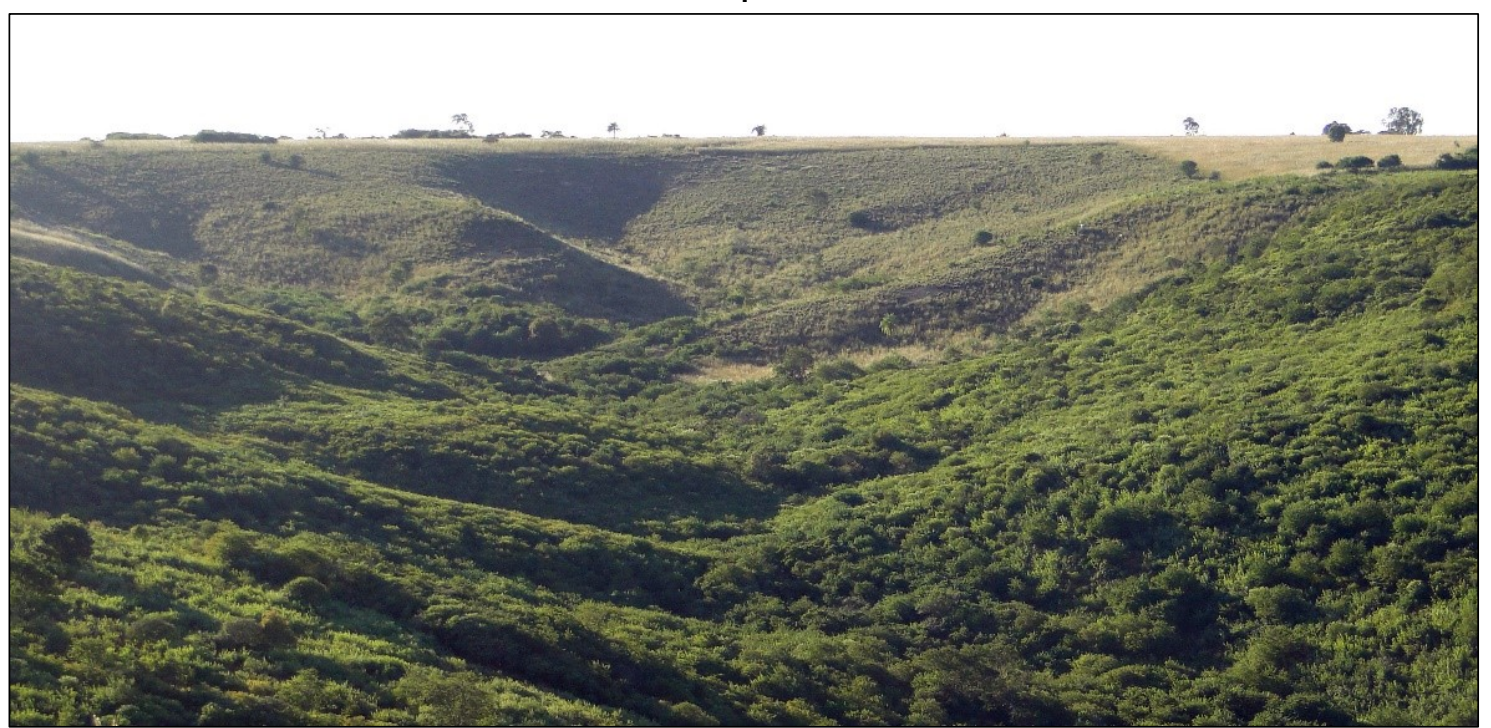

Figura 4: Topo aplainado sustentado por nível laterítico, Altaneira, Ceará Foto: Levantamento de campo (2016). 
Essas coberturas ferruginosas foram formadas, no Eoceno (PEULVAST; BÉTARD, 2015), como resultado do acentuado intemperismo químico ao qual toda a região Nordeste foi submetida durante o Paleógeno e, menos intensamente no Neógeno, quando ocorreram grandes variações entre períodos de clima úmido e seco (MORAIS NETO et al., 2005). O resultado desses processos produziu no embasamento granítico, extensos e espessos mantos de laterita, caracterizados pela presença óxidos e hidróxidos de ferro supergênicos. As exposições mais expressivas dos mantos de laterita podem ser observadas, nos diversos platôs presentes, na porção sudoeste do maciço, nos arredores do município de Altaneira.

A Serra do Quincuncá, na sua porção oriental, também, é recortada por falhas indiscriminadas, as quais confinam a Suíte Serra do Deserto, que funciona como um contraforte, com cerca de $610 \mathrm{~m}$ de altitude, proporcionando uma topografia aplainada, levemente dissecada por canais fluviais, o que lhe confere uma morfologia atípica em se tratando de maciços cristalinos do semiárido cearense. Essa superfície de cimeira é delimitada por uma escarpa erosiva, com declividade entre 20 a $45^{\circ}$ (Figura 5).

$\mathrm{Na}$ área de estudo, as zonas de deformação de direção NE-SW, marcadas por heterogeneidade litológica, exercem importante influência no controle estrutural da drenagem e na dissecação dos compartimentos geomorfológicos. O condicionamento dos processos erosivos ao longo das zonas de cisalhamento originou trends de lineamentos que confinam os canais de drenagem, a oeste e leste da Serra do Quincuncá, orientando a dissecação e por vezes a agradação fluvial. Isso resultou numa sequência de cristas de cinemática NE-SW (Figura 6), que desempenham um papel importante na dissecação, e vales, dispostos paralelamente, a exemplo de modelos apalacheanos, que confinam os canais de escoamento, passando a serem indicadores dos planos de deformação.

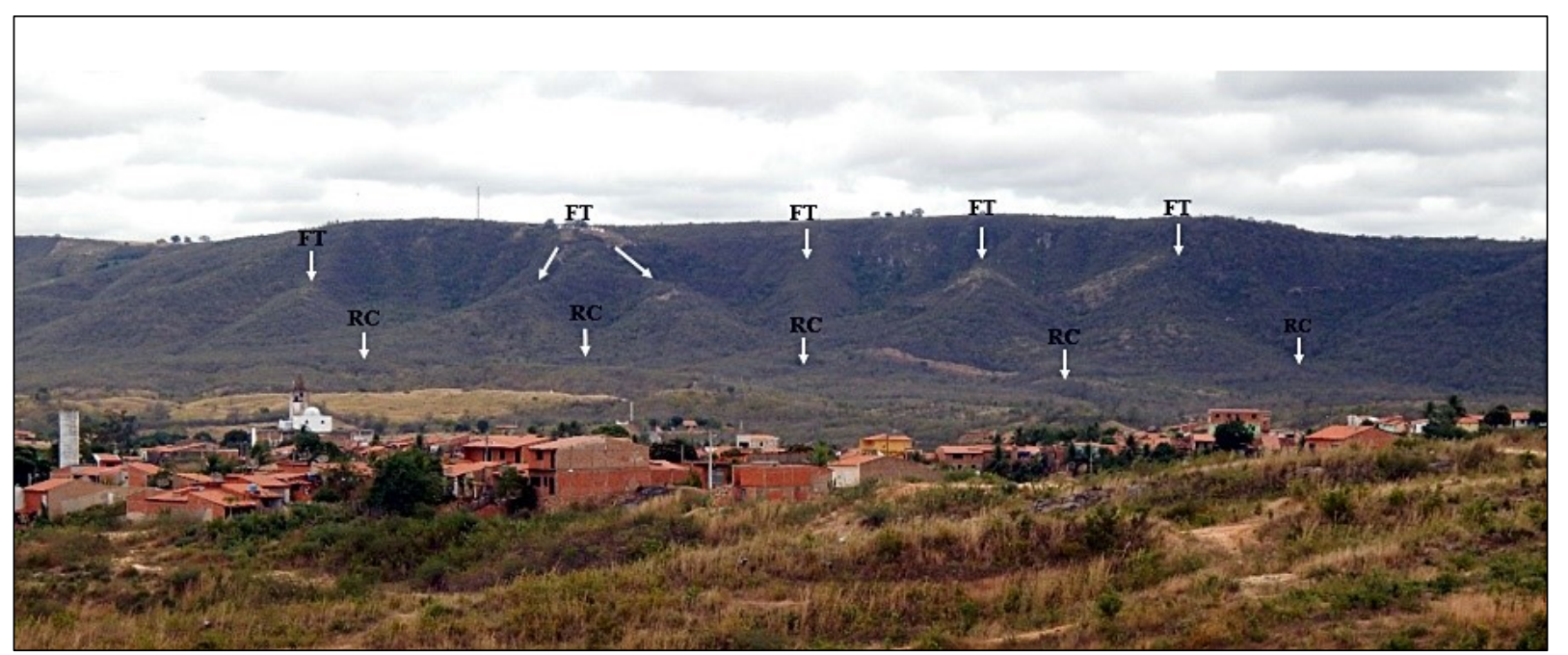

Figura 5: Visada parcial da escarpa erosiva da Serra do Quincuncá, onde: (FT) indica feições semelhantes a Facetas Triangulares e (RC) Rampa de Colúvio. Notar a morfologia aplainada do topo. Foto: Levantamento de campo (2016). Elaboração: Autor (2016).

Os processos morfogenéticos de evolução da Serra do Quincuncá indicam claramente a retração lateral de suas encostas por backwearing com rebaixamento contínuo de sua verticalização por downwearing e deposição de material coluvial através de movimentos de massa em eventos pretéritos, no sopé do maciço, formando rampas de colúvio. A evolução integrada das encostas, da porção oriental da Serra do Quincuncá, por recuo diferencial, e dos canais fluviais, possivelmente, durante o Quaternário, documenta uma fase de origem de cabeceiras de drenagem em anfiteatro (hollows) e de entulhamento generalizado dos fundos de vale fluviais por material coluvial, que com a retomada erosiva holocênica se interdigitam e/ou recobrem depósitos aluviais.

A depressão sertaneja, que é circundenudacional em relação ao maciço, proveniente de atividades exodinâmicas, representa o mais expressivo compartimento do relevo, da área de estudo. Com os processos morfodinâmicos, foram elaboradas feições dissecadas pelos entalhes 
provenientes da drenagem superficial, sobretudo, por incisão linear, constituindo cristas residuais e inselbergs, testemunhos de níveis originários mais resistentes, que permanecem na área isoladamente, consequentes de erosão circundante, além de rampas de colúvio, que marcam o limite entre o maciço e a depressão sertaneja, e pequenas planícies alveoloraes, distribuídas de forma escalonada no maciço e aleatória na superfície sertaneja.

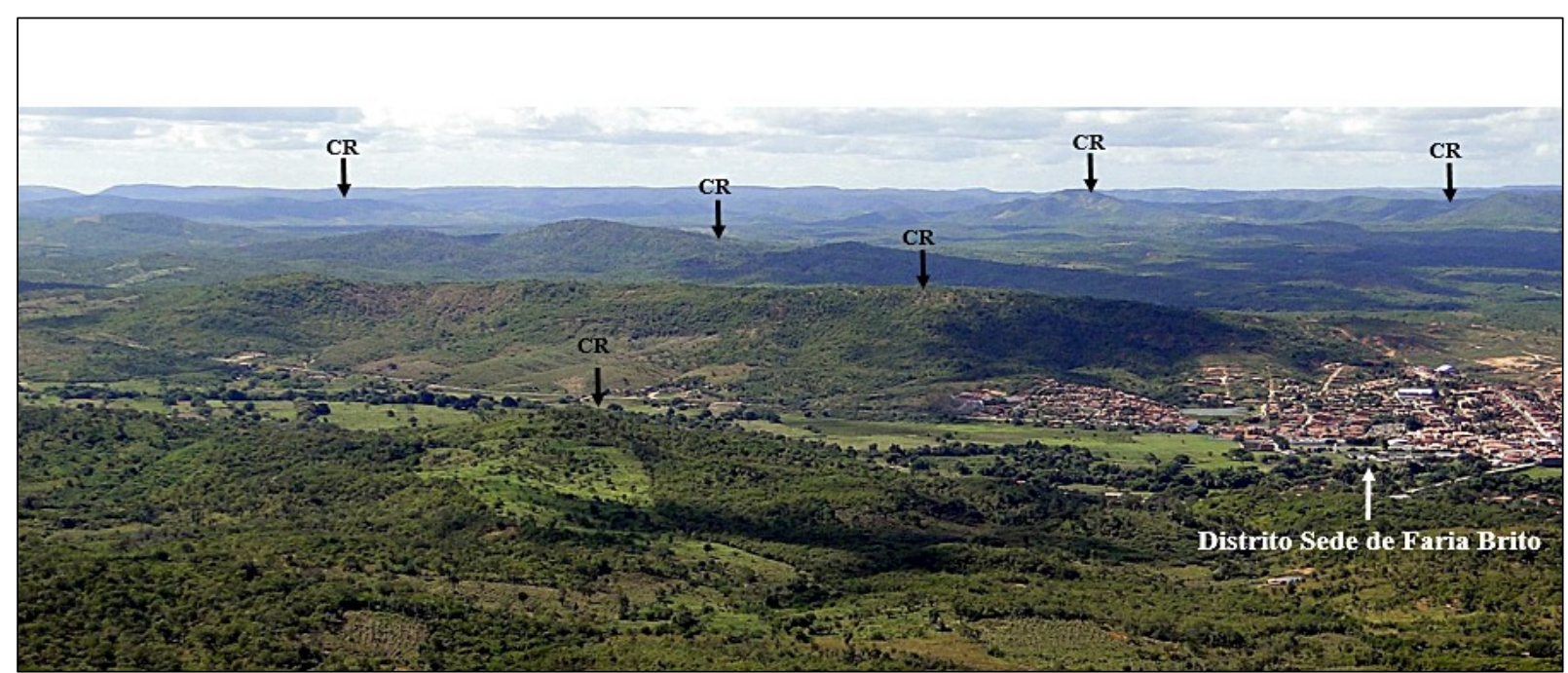

Figura 6: Cristas residuais (CR) nas proximidades do município de Farias Brito, Ceará. Foto: Levantamento de campo (2015). Elaboração: Autor (2016).

No setor meridional da área de estudo, também, foram observadas, colinas semiconvexas. Nessa superfície subúmida, a erosão fluvial em litologias que não apresentam controle estrutural marcante, em decorrência da ausência de planos de deformação, evidenciou feições suavemente arredondadas (meias-laranjas), com diferentes graus de dissecação. Portanto, os processos denudacionais, da área de estudo, vêm ao longo dos tempos geológicos colocando em ressalto as estruturas rochosas sustentadas preferencialmente por granitos, quartzitos, ortognaisses e até mesmo metacalcários da Formação Faria Brito, e rebaixando o relevo constituído por litologias menos resistentes como os micaxistos da Formação Caipu e gnaisses da Formação Farias Brito. Por sua vez, os tratos mais baixos e planos encontram-se nas planícies fluviais, com destaque para as planícies dos rios Cariús, Bastiões e Jaguaribe (Figura 7).

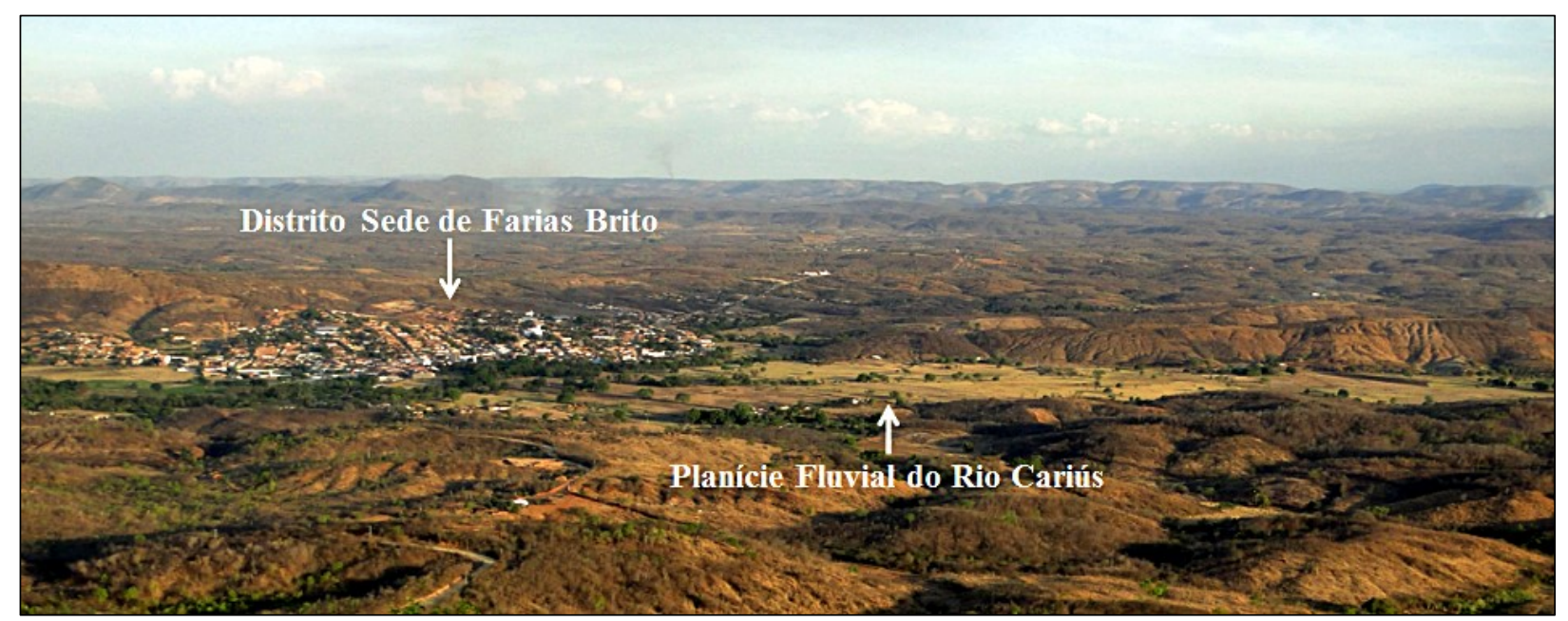

Figura 7: Vista parcial da planície fluvial do médio curso do rio Cariús. Notar em segundo plano o Distrito Sede de Farias Brito, Ceará. Foto: Levantamento de campo (2015). Elaboração: Autor (2016). 
A classificação genética dos rios Cariús, Bastiões e Jaguaribe mostra-os, especificamente, na área de estudo, como subsequentes, cuja direção do fluxo é controlada pela estrutura rochosa, acompanhado, em grande parte, zonas de fraqueza, e consequentes, onde o curso coincide com à inclinação das camadas geológicas. O padrão de drenagem obedece a uma tendência dendrítica ou subdendrítica na Serra do Quincuncá e, treliça e retangular nos sertões dissecados e aplainados, tendendo a paralelismo dos cursos d'água, não formando canais expressivos, na área de contato do cristalino com a depressão periférica da Bacia do Araripe, no município de Nova Olinda.

$\mathrm{Na}$ área de estudo, o aporte de águas subterrâneas é modesto ou escasso. Em grande parte, compõem reservatórios subterrâneos diversos em arranjos estruturais, falhas/zonas fraturadas, rochas intemperizadas e depósitos holocênicos aluviais ou alúvio-colúviais nas planícies fluviais e alveolares.

A irregularidade das precipitações, mesmo na estação chuvosa e a concentração no tempo, traz reflexos marcantes no escoamento superficial. Este também é afetado, diretamente, pelo grau de declividade do relevo e pela impermeabilidade das rochas. Tais características aliam-se para impor um escoamento intermitente e torrencial não só nos principais cursos d'água, como a alguns tributários de maior vazão. No entanto, a insuficiência de chuvas decorre mais da irregularidade ou variabilidade anual do que de seus totais pluviométricos padrões. Os postos pluviométricos inseridos na área de estudo estão sujeitos aos mesmos e simultâneos fenômenos dinâmicos de perturbação atmosférica: Complexos Convectivos de Mesoescala (CCM's), Vórtices Ciclônicos de Altos Níveis (VCAN), Zona de Convergência Intertropical (ZCIT) e os ventos alísios de SE.

A maior concentração pluviométrica para os 25 anos analisados (1990-2015), de dados da FUNCEME, ocorre no primeiro semestre, onde se tem aproximadamente $89,35 \%$ do total anual, sendo o mês de março o mais chuvoso com $184,59 \mathrm{~mm}(23,68 \%)$. O trimestre menos chuvoso abrange o período julho-agosto-setembro, com mínimas registradas em agosto-setembro.

A pré-estação é compreendida pelos meses de dezembro e janeiro, apresentando uma média mensal de $45 \mathrm{~mm}$ e $131 \mathrm{~mm}$, respectivamente. Neste período as chuvas são produzidas, principalmente, pela formação dos CCM's e VCAN, sistemas secundários de circulação atmosférica, que se formam devido à proximidade de frentes frias (CEARÁ, 2012).

O período de fevereiro a maio que corresponde à quadra chuvosa representa $70,89 \%$ da média pluviométrica anual de $779,51 \mathrm{~mm}$. A ZCIT é o principal sistema sinótico provocador da quadra chuvosa, atuando de modo mais expressivo a partir de meados do verão, e atingindo sua maior frequência no outono (março-abril), quando alcança sua posição mais meridional. O mês de maio é caracterizado pelo início do afastamento da ZCIT.

A estação seca inicia-se em meados de junho e julho, indo até outubro-novembro. O período de estiagem coincide com a chegada dos ventos alísios de SE, vinculados ao Anticiclone Semifixo do Atlântico Sul, produtor da Massa Equatorial Atlântica, responsável pela estabilidade do tempo no segundo semestre.

A partir do exposto fica evidente que a principal marca da precipitação na área de estudo não é o total pluviométrico, mas sim sua distribuição temporal e espacial, sobretudo pela concentração ao longo do ano. Como se pode observar, o regime de chuvas da área de estudo, como em toda a região semiárida do Nordeste do Brasil, é bastante regular, uma vez que, embora sejam muito irregulares os totais pluviométricos da estação chuvosa, esta se dá como vimos, quase sempre nos meses de verão-outono. Entretanto, a que se considerar a importância da exposição (NE-SW) e das altitudes variáveis $(450-730 \mathrm{~m})$ da Serra do Quincuncá na produção de chuva. Essas condições favorecem a ascensão forçada das massas de ar úmidas oriundas do litoral setentrional, que chegam a região pela calha do rio Jaguaribe, formando nebulosidade, e aumentando a atividade convectiva por ocasião do período chuvoso, o que cria condições favoráveis para atenuar a semiaridez durante a estação seca. Isso é nitidamente observado na porção oriental do maciço, assim como na superfície sertaneja, situada a barlavento, onde os processos morfodinâmicos apresentam níveis de dissecação verticais mais acentuados e os mantos de intemperismo são mais espessos. Portanto, dentro do contexto da Serra do Quincuncá, observa-se que os totais pluviométricos mensais são significativamente superiores nos setores a 
barlavento do maciço e no município de Altaneira, localizado a $670 \mathrm{~m}$ de altitude no platô serrano. Já na vertente ocidental, onde se evidencia uma faixa transicional do maciço com as condições semiáridas dos sertões circunvizinhos dos municípios de Assaré e Tarrafas, ocorre um sensível decréscimo das precipitações.

A influência direta da Serra do Quincuncá, nos totais pluviométricos e, consequentemente, nas paisagens sertanejas, situadas a sotavento, onde maiores deficiências hídricas se evidenciam, pode ser constatada quando se compara o comportamento das precipitações anuais dos municípios de Farias Brito e Tarrafas, onde a diferenciação pluviométrica entre áreas próximas é considerável (Figura 8).

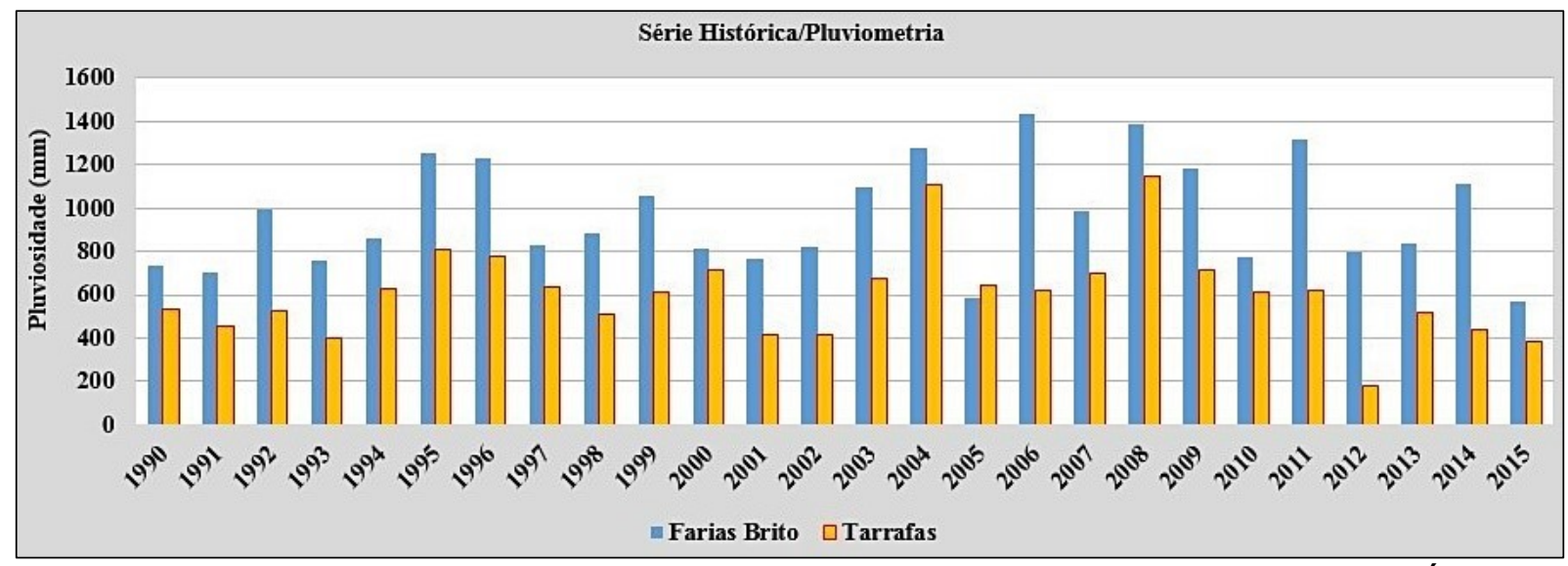

Figura 8: Série histórica dos municípios de Farias Brito e Tarrafas, Ceará Fonte: CEARÁ - Postos Pluviométricos (2016). Elaboração: Autor (2016).

É importante destacar que as sedes municipais desses dois municípios estão situadas a uma distância de apenas $33,5 \mathrm{~km}$, e o que faz com que haja esta diferença pluviométrica é, principalmente, o posicionamento geográfico desses municípios. Onde Farias Brito está situado no setor de barlavento, a uma altitude de $320 \mathrm{~m}$, com média pluviométrica de $1000 \mathrm{~mm} / a n o$, enquanto Tarrafas, que está situado na depressão sertaneja, a uma altitude de $300 \mathrm{~m}$ acima do nível do mar, e a sotavento desse maciço, apresenta uma média pluviométrica de $631 \mathrm{~mm} / \mathrm{ano}$.

A classificação climática da área de estudo foi realizada a partir do balanço hídrico climático proposto por Thornthwaite e Mather (1955). A distribuição climática, de acordo com a metodologia adotada, indica três tipos climáticos: subúmido, em Altaneira; subúmido seco, em grande parte dos municípios de Assaré, Farias Brito, Nova Olinda e Santana do Cariri; e semiárido, em Aiuaba, Cariús, Jucás, Saboeiro e Tarrafas.

A área compreendida pela Serra do Quincuncá e entorno, destaca, no seu conjunto, além das diferentes posições topográficas, que influenciam nas condições climáticas e na cobertura vegetal, uma grande heterogeneidade litológica, que incide, igualmente, sobre a grande diversidade de solos.

Dentro dessa perspectiva, sobre um arcabouço de rochas cristalinas subjacentes e pelos processos pedogenéticos, à mercê da topografia, predominam na paisagem da área de estudo, as seguintes classes de solo: Neossolo Litólico Eutrófico, Nitossolo Vermelho Eutrófico, Argissolo Amarelo Distrófico, Argissolo Vermelho Eutrófico, Plintossolo Pétrico Concrecionário, Neossolo Flúvico Ta Eutrófico, Cambissolo Háplico Ta Eutrófico e Chernossolo Háplico Órtico típico. Todavia esses solos ocorrem sempre em associações com outros menos desenvolvidos.

As três primeiras classes (Neossolos, Nitossolos e Argissolos) são amplamente predominantes e compõem as principais associações de classes de solos. As demais classes ocorrem em proporções menores, porém, ocupando uma parcela significativa da área de estudo, configurando as associações de solos predominantes nas superfícies sertanejas.

No cenário das superfícies sertanejas, em razão de uma maior variabilidade do material geológico, combinada com condições de semiaridez mais severas, ocorre uma maior diversidade de classes. Neste cenário predominam os Neossolos Litólicos, solos rasos, pouco desenvolvidos, 
com fragmentos de rocha, que apresentam contato lítico ou lítico fragmentário dentro de $50 \mathrm{~cm}$ da superfície do solo, com horizonte A disposto sobre a rocha.

O Nitossolo Vermelho Eutrófico típico tem ocorrência em vários ambientes da área de estudo, sobretudo na superfície de cimeira aplainada e na vertente ocidental da Serra do Quincuncá, como nos topos de algumas cristas residuais e colinas, no município de Nova Olinda, constituindo a segunda classe de solo com maior representatividade espacial.

Os Argissolos Vermelho Eutrófico constituem a terceira classe de solo, ocorrem, praticamente, em toda a área de estudo. Ou seja, têm sua distribuição bastante variada, cobrindo desde superfícies de topografia pouco movimentada, com declives variáveis de 3 a $8^{\circ}$, até superfícies de topografia movimentada, com declives fortes, entre 20 a $45^{\circ}$.

$\mathrm{Na}$ área de estudo, a morfopedologia condiciona nas planícies fluviais a ocorrência de Neossolo Flúvico Ta Eutrófico. Já nas áreas de acumulação inundáveis, se distribuem, principalmente, solos hidromórficos, com associações de Planossolo Nátrico Órtico típico. De modo geral são solos de grande potencialidade agrícola em razão de sua alta fertilidade natural e posição na paisagem, que facilita a mecanização.

$\mathrm{Na}$ área de estudo, há um recobrimento predominante das formações de caatingas, que ostentam variados padrões fisionômicos e florísticos: Caatinga arbustiva e arbórea. A área de exceção fica circunscrita às matas ciliares que revestem as planícies fluviais.

A Caatinga arbórea ocupa o terço médio e superior da Serra do Quincuncá, além do seu platô e da superfície elevada de erosão (etch surface), exposta a partir da dissecação do capeamento laterítico, onde as condições climáticas são mais amenas. As áreas ocupadas por essa vegetação são intensamente exploradas pelas culturas de ciclo longo e curto, em virtude do caráter eutrófico dos solos.

A Caatinga arbustiva esparsa, em regra, recobre o terço médio das vertentes da Serra da Quincuncá e os níveis mais rebaixados da área de estudo, abaixo da cota de $450 \mathrm{~m}$. Essa formação vegetacional é lenhosa, com porte variável, caráter xerófilo, apresentando cactáceas e bromeliáceas. No entanto, em consequência dos desmatamentos indiscriminados associados aos cultivos de sequeiro e a pecuária extensiva, essa unidade vegetacional apresenta redução do tamanho populacional com correspondente perda de variabilidade genética, sendo substituída por espécies herbáceas.

\subsection{Unidades Geomorfológicas}

A compartimentação geomorfológica da Serra do Quincuncá e do entorno imediato foi elaborada, segundo as características morfológicas do relevo. Esse critério é muito adotado em estratégias de planejamento ambiental ou ordenamento territorial e isso se explica devido à similaridade dos demais componentes ambientais constatada em cada compartimento geomorfológico mapeado na escala de 1:250.000.

Ab'Sáber (1969) destaca a compartimentação da topografia regional como $01^{\circ}$ nível de tratamento em pesquisas geomorfológicas, assim como a caracterização e descrição das formas de relevo de cada um dos compartimentos estudados, e que se apresenta de fundamental importância em estudos voltados para planejamento ambiental.

Tendo em vista o critério geomorfológico citado, a área de estudo foi dividida em duas grandes unidades morfoestruturais: superfícies elevadas e rebaixadas, sendo individualizadas em superfícies morfoesculturais distintas (Figura 9).

As superfícies elevadas compreendem os setores situados acima da cota 450m, localizados no maciço granítico e na porção meridional da área. Já as superfícies rebaixadas abrangem as superfícies sertanejas dissecadas. Esse tipo de compartimentação geomorfológica permite adotar as unidades mapeadas como unidades de planejamento ambiental, onde cada uma dessas unidades apresenta potencialidades e limitações específicas, que farão parte de pesquisas futuras. 


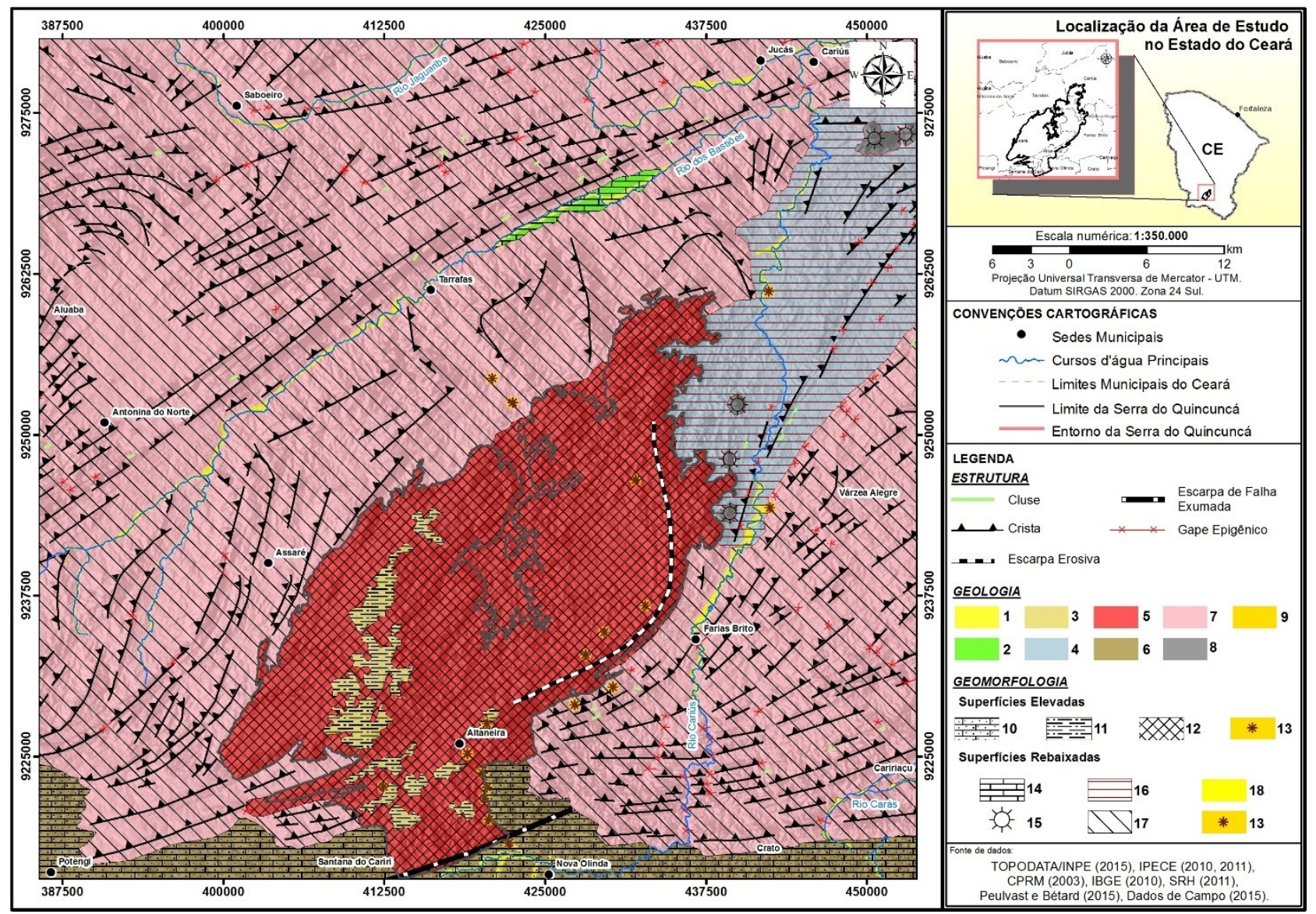

Figura 9: Compartimentação geomorfológica da Serra do Quincuncá e entorno. Fonte: elaborado pelo autor (2016). Legenda: 1. Areias quartzosas e argilosas; 2. Arenitos; 3. Cobertura eluvial: alteração "in situ" de rochas intrusivas; 4. Gnaisses e micaxistos; 5 . Granitos; 6.Ortognaisses, gnaisses, micaxistos e coberturas sedimentares mesopaleozoicas; 7. Ortognaisses, micaxistos, gnaisses e granitoides; 8. Quartzodioritos; 9. Areias finas, grossas e argilosas; 10. Superfície Sertaneja Dissecada em Colinas e Morros; 11. Sup. Tabular; 12. Ecth Surface; 13. Planície Alveolar; 14. Bacia dos Bastiões; 15. Inselberg; 16. Sup. Sertaneja Dissecada; 17. Sup. Sertaneja Dissecada em Cristas; 18. Planície Fluvial.

\subsubsection{Superfícies Elevadas}

\subsubsection{Superfície de Erosão Dissecada (Etch Surface)}

A superfície de erosão dissecada ocupa uma área de $776,86 \mathrm{~km}^{2}$ e corresponde a superfície de cimeira da Serra do Quincuncá, identificada por sua forma alongada e de cinemática dextral. Essa superfície apresenta, na porção oriental, relevo composto por escarpa erosiva festonada pela dissecação fluvial e topo suavemente dissecado com reverso intensamente meteorizado e dissecado, principalmente, nas áreas de intrusão da Suíte Gabroide.

A etch surface apresenta a maior declividade da área de estudo, com predominância acima de $35^{\circ}$ de inclinação, e com altimetrias variáveis que podem ir desde 380 a $660 \mathrm{~m}$. Entretanto, o que caracteriza a escarpa erosiva são os processos de seccionamento realizados pelos canais de primeira ordem que avançam regressivamente, respondendo por escarpas íngremes com cabeceiras de drenagem em evolução, intermitentes e semiperenes, que evidenciam estágios diferentes de evolução da drenagem.

A superfície de erosão dissecada, também, apresenta, na sua porção oriental, uma topografia peculiar, com topo aplainado, separados por pequenas incisões fluviais, o que the confere uma morfologia atípica em se tratando de superfície de cimeira de relevos cristalinos residuais do Nordeste brasileiro. Trata-se de platô da ordem de $610 \mathrm{~m}$ de altitude mantido por augenortognaisses graníticos da Suíte Serra do Deserto, que compõe estruturalmente o setor oriental do maciço. 
De modo distinto, no decorrer do Eoceno, Paleógeno médio, os granitos, granodioritos e augenortognaisses que compõem a Serra do Quincuncá, foram submetidos a longo período de intenso intemperismo químico e lixiviação, que originaram mantos de alteração de espessura métrica e formações supergênicas autóctones, de idade pré-Neógena ( 43 Ma) (Peulvast \& Bétard, 2015), representadas por diferentes fases de formação de perfis lateríticos, responsáveis pelo recobrimento da superfície de cimeira do maciço. Entretanto, no decorrer do Oligoceno, o capeamento laterítico foi, parcialmente, dissecado, expondo a etch surface (front de alteração) aos processos intempéricos e denudacionais. Portanto, a superfície de erosão elevada foi formada a partir de um retrabalhamento acíclico por etchplanation e downwearing, através de alternâncias de episódios de intemperismo (etching) e erosão (stripping), essencialmente controlados pelas variações do clima regional.

\subsubsection{Superfície Sertaneja Dissecada em Colinas e Morros}

A superfície sertaneja dissecada em colinas e morros, ocupando uma área de $277,55 \mathrm{~km}^{2}$, localizase na porção meridional da área de estudo, situada numa faixa aproximadamente $\mathrm{E}-\mathrm{W}$, entre a Chapada do Araripe e a Serra do Quincuncá. Sua altitude média varia de 380 a $660 \mathrm{~m}$, com vertentes apresentando declividades entre 8 a $20^{\circ}$. Os vales são abertos a fechados, tendo planícies colúvio-aluviais encaixadas e restritas, cuja declividade não ultrapassa os $3^{\circ}$.

A característica mais peculiar dessa superfície é a ausência de lineamentos estruturais e uma diminuição na densidade da rede de drenagem, apresentando padrão de drenagem dendrítico e paralelo. O padrão paralelo está associado ao controle estrutural exercido pelas coberturas fanerozoicas da Chapada do Araripe, que por sua vez formam vales encaixados, exibindo interflúvios alongados.

A morfologia convexa dos topos das colinas é resultado da dissecação linear fluvial que varia, em determinados locais, em função do grau de incisão dos canais fluviais, evidenciando que as características geométricas dessas feições estão mais associadas ao padrão de dissecação fluvial e a ausência de lineamentos estruturas que, evidentemente, ao tipo litológico que a sustenta. É esse grau de incisão que define a diferença entre colinas convexas e semiconvexas.

\subsubsection{Superfície Tabular}

Essa superfície ocupa uma área de $60 \mathrm{~km}^{2}$, entre as cotas 660 e $730 \mathrm{~m}$ aproximadamente. A principal particularidade desta unidade é a presença de coberturas lateríticas bem conservadas, observadas, principalmente, no município de Altaneira e Assaré. Esses platôs, capeadas por laterita, constituem formas residuais de um antigo capeamento contínuo, que foi formado no Eoceno (Peulvast \& Bétard, 2005), como resultado do acentuado intemperismo químico ao qual toda a região Nordeste foi submetida durante o Paleógeno e, menos intensamente no Neógeno, quando ocorreram grandes variações entre períodos de clima úmido e seco (MORAIS NETO; HEGARTY; KARNER, 2005), que precederam as condições semiáridas atuais dos sertões nordestinos. Portanto, a presença de perfis de intemperismo laterítico em diferentes platôs localizados nessa superfície pode ser um indicador que, em algum momento de sua história geológica, a superfície de cimeira da Serra do Quincuncá encontrava-se recoberta por esse manto de intemperismo autóctone, e que processos erosivos atuaram proporcionando a dissecação e fragmentação do capeamento laterítico. Nos setores onde capeamento laterítico foi removido, o front de alteração foi exposto (etch surface).

\subsubsection{Superfícies Rebaixadas}

\subsubsection{Superfície Sertaneja Dissecada}

Ocupando uma área de $360,40 \mathrm{~km}^{2}$, essa superfície compreende a porção mais suavizada do relevo da área, desenvolvida sobre gnaisses da Formação Farias Brito e micaxistos da Formação Caipu. A declividade média é de $8^{\circ}$, podendo variar de 20 a $45^{\circ}$ nos relevos residuais com vertentes íngremes. A amplitude do relevo é de pouco mais de $70 \mathrm{~m}$, estando a cota mais alta a $606 \mathrm{~m}$, nos inselbergs que pontilham essa superfície, constituídos por quartzodioritos e 
sienogranitos gnaissificados da Suíte Serra do Deserto. Nessa superfície a erosão progride tanto pelo ataque da rocha sã ao nível de um front de meteorização quanto pela remoção do material alterado pelo escoamento superficial (etchplanation).

No setor sudeste dessa superfície a taxa de denudação ultrapassa a do intemperismo por uma conjunção de diversos fatores: processo tectônico, responsável pelo soerguimento regional no Oligoceno (Morais Neto, Hegarty \& Karner, 2005), que proporcionou etapas de incisão fluvial e degradação do relevo; alternâncias climáticas em períodos relativamente curtos desde meados do Mioceno, onde a existência, no Nordeste brasileiro, nos últimos $13 \mathrm{Ma}$, do clima semiárido (THIRY; SCHMITT; SIMON-COINÇON, 2009), provocou uma fase de denudação intensa e erosão diferencial; e a presença de contrastes litológicos, que não oferecem resistência aos processos intempéricos, além da supressão da cobertura vegetal, que constitui uma transição de caatinga hipoxerófila para cerrado subcaducifólio. A soma desses fatores proporcionou a exposição da frente de intemperismo, nessa superfície.

\subsubsection{Superfície Sertaneja Dissecada em Cristas}

Essa superfície, que representa quase a totalidade da área $\left(3.117 \mathrm{~km}^{2}\right)$, é caracterizada pelo nítido controle estrutural sobre a morfologia atual, representada pelo alinhamento de um feixe de cristas residuais, com orientação NE-SW, que confinam a drenagem de primeira ordem e orientam a dissecação. Os cursos d'água, nessa superfície, geralmente formam pequenas planícies fluviais, com exceção do rio Cariús, Bastiões, e Jaguaribe, em cotas altimétricas, normalmente, inferiores a $310 \mathrm{~m}$. O padrão de drenagem do tipo treliça contrasta com o retangular, indicando importante estruturação tectônica.

As cristas residuais apresentam vertentes convexas e retilíneas com declividades variando de 20 a $35^{\circ}$. Essas feições também apresentam topos convexos que definem um modelado ondulado a forte ondulado ao relevo, com as altitudes variam de 310 a $660 \mathrm{~m}$.

Nessa superfície, nas proximidades do município de Tarrafas, encaixada entre superfícies com ondulações bastante acentuadas e constituídas por granitos e granodioritos da Suíte Itaporanga e por ortognaisses migmatizados do Complexo Jaguaretama, nas margens do rio dos Bastiões, encontra-se a Bacia Sedimentar do Rio dos Bastiões (bacia pull-apart), datada do Valanginiano, com $9 \mathrm{~km}^{2}$, cuja formação, possivelmente, acha-se relacionada à reativação mesozoica da Plataforma Sul Americana.

\section{CONSIDERAÇÕES FINAIS}

O estudo geomorfológico e a leitura do quadro natural da Serra do Quincuncá permitiram o estabelecimento de relações estreitas entre as características litoestruturais, climáticas, paleoclimáticas e a distribuição dos modelados. As zonas de cisalhamento e a heterogeneidade litológica aparecem como parâmetros estruturais fundamentais no condicionamento do relevo. Nesse aspecto, o modelado é influenciado por estruturas de subsuperfície de formação tectônica datadas do Neoproterozoico, que foram reativadas de forma rúptil no Neocomiano e, possivelmente, em períodos pós-Cretáceo.

Em adição, a identificação dos diferentes padrões de organização do relevo através do mapa geomorfológico da Serra do Quincuncá é uma importante ferramenta para o entendimento da dinâmica da componente abiótica da paisagem, podendo servir de referência na perspectiva de uma melhor caracterização do ambiente físico dos maciços residuais que pontuam o semiárido cearense, além de fornecer a administração pública e à sociedade em geral subsídios para planejamento ambiental. 


\section{REFERÊNCIAS}

AB'SÁBER, A. N. Um conceito de Geomorfologia a serviço das pesquisas sobre o Quaternário. Geomorfologia, v. 18, n. 1, p. 1-23, 1969.

. Sertões e sertanejos: uma geografia humana sofrida. Estudos avançados, v. 13, n. 36, p. 7-59, 1999.

BRASIL. Companhia de Pesquisa de Recursos Minerais-CPRM. Atlas digital de geologia e recursos minerais do Ceará. Mapa na escala de 1:500.000. Fortaleza: Serviço Geológico do Brasil/Ministério das Minas e Energia, 2003.

Banco do Nordeste do Brasil-BNB. Proposta de dimensionamento do semiárido brasileiro. Fortaleza: BNB, 2005. 108p.

BRITO NEVES, B. B. de; CAMPOS NETO, M. da C.; VAN SCHMUS, W. R.; SANTOS, E. J. dos. O "Sistema Pajeú-Paraíba" e o "Maciço São José do Campestre" no leste da Borborema. Revista Brasileira de Geociência, v. 31, n. 2, p. 173-184, 2001.

CASTRO, D. L. de; BEZERRA, F. H. R.; SOUSA, M. O. L.; FUCK, R. A. Influence of Neoproterozoic tectonic fabric on the origin of the Potiguar Basin, northeastern Brazil and its links with West Africa based on gravity and magnetic data. Journal of Geodynamics, v. 54, p. 29-42, 2012.

CEARÁ. Fundação Cearense de Meteorologia e Recursos Hídricos-FUNCEME. Levantamento de reconhecimento de média intensidade dos solos: mesorregião do sul cearense. Fortaleza: FUNCEME, 2012. 132p.

Fundação Cearense de Meteorologia e Recursos Hídricos-FUNCEME. Postos pluviométricos. Acesso em 20 de agosto, 2016, de http://www.ipece.ce.gov.br/perfil_basico/perfil-basico-municipal-2015.html.

CORREAA, A. C. de B.; TAVARES, B. de A. C.; MONTEIRO, K. de A.; CAVALCANTI, L. C. de S.; LIRA, D. R. Megageomorfologia e morfoestrutura do Planalto da Borborema. Revista do Instituto Geológico, v. 31, n. 1/2, p. 35-52, 2010.

GURGEL, S. P. de P.; BEZERRA, F. H. R.; CORREAA, A. C. de B.; MARQUES, F. O.; MAIA, R. P. Cenozoic uplift and erosion of structural landforms in NE Brazil. Geomorphology, v. 186, p. 6884, 2013.

MAIA, R. P.; BEZERRA, F. H. R. Condicionamento estrutural do relevo no Nordeste setentrional brasileiro. Mercator, v. 13, n. 1, p. 127-141, 2014.

MAIA, R. P.; BÉTARD, F.; BEZERRA, F. H. R. Geomorfologia dos maciços de Portalegre e Martins-NE do Brasil: inversão do relevo em análise. Revista Brasileira de Geomorfologia, v. 17, n. 2, p. 273-285, 2016.

MORAIS NETO, J. M. de; HEGARTY, K.; KARNER, G. D. Abordagem preliminar sobre paleotemperatura e evolução do relevo da bacia do Araripe, Nordeste do Brasil, a partir da análise de traços de fissão em apatita. Boletim de Geociências da Petrobrás, v. 14, n. 1, p. 113-119, 2015.

NASCIMENTO, M. A. L.; MEDEIROS, V. C. de.; GALINDO, A. C. Ediacaran to Cambrian magmatic suites in the Rio Grande do Norte domain, extreme Northeastern Borborema Province (NE of Brazil): current knowledge. Journal of South American Earth Sciences, v. 58, p. 281-299, 2015.

PEULVAST, J. P.; BÉTARD, F. A history of basin inversion, scarp retreat and shallow denudation: the Araripe basin as a keystone for understanding long-term lasdscape evolution in NE Brazil. Geomorphology, 233, p. 20-40, 2015.

PEULVAST, J. P.; CLAUDINO SALES, V. Mapa morfoestrutural do Ceará e áreas adjacentes do Rio Grande do Norte e da Paraíba. In: Brasil. Atlas digital de geologia e recursos minerais do Ceará. Mapa na escala 1:500.000. Fortaleza: Serviço Geológico do Brasil, 2003. 
PEULVAST, J. P.; CLAUDINO SALES, V. Evolução morfoestrutural do relevo da margem continental do Estado do Ceará, Nordeste do Brasil. Caminhos da Geografia, v. 7, n. 20, p. 121, 2007.

RODRIGUES, S. W. de O.; ARCANJO, C. J. Estruturas e histórias deformacionais contrastantes dos granitos sintectônicos de Campina Grande e Serra Redonda, Província Borborema, NE do Brasil. Geologia USP, Revista do Instituto de Geociências da USP, v. 11, n. 1, 3-17, 2011.

SCHOBBENHAUS, C.; CAMPOS, D. A.; DERZE, G. R.; ASMUS, H. E. Geologia do Brasil: texto explicativo do mapa geológico do Brasil e da área oceânica adjacente incluindo depósitos minerais, escala 1:2.500.000. Brasília: DNPM, 1984. 501p.

THIRY, M.; SCHMITT, J. M.; SIMON-COINÇON, R. Problems, progress and future research concerning palaeoweathering and palaeosurfaces. p. 1-17. In: THIRY, M.; SIMON-COINÇON, $\mathrm{R}$ (Eds.). Palaeoweathering, palaeosurfaces and related continental deposits. International Association of Sedimentologistis. Special Publication, n. 7. Nova Jersey: Blackwell Science, 2009.

THORNTHWAITE, C. W.; MATHER J. R. The water balance climatology, v. 8, n. 1. Centerton: Drexel Institute of Technology-Publications in Climatology, 1955. 104p.

VAUCHEZ, A.; NEVES, S.; CABY, R.; CORSINI, M.; EDYDIO-SILVA, M.; ARTHAUD, M.; AMARO, $V$. The Borborema shear zone system, NE Brazil. Journal of South American Earth Sciences, v. 8, n. 3/4, p. 247-266, 1995. 